\title{
ANJUNGAN KULINER NUSANTARA
}

\author{
Ria Iryani Wijaya ${ }^{1)}$, Dewi Ratnaningrum ${ }^{2)}$ \\ 1) Program Studi S1 Arsitektur, Fakultas Teknik, Universitas Tarumanagara, riairyaniwijaya@gmail.com \\ 2) Program Studi S1 Arsitektur, Fakultas Teknik, Universitas Tarumanagara, dewir@ft.untar.ac.id
}

\begin{abstract}
Abstrak
Kota Jakarta merupakan salah satu Kota Metroplis di Indonesia, yang memiliki tingkat stress serta penat yang tinggi, yang berasal dari berbagai faktor yang ada, di antaranya pola kegiatan sehari-hari yang berulang, macet, polusi dan lain sebagainya. Hal tersebut merupakan salah satu contoh pentingnya wisata rekreasi dalam suatu kota metropolis untuk menekan tingkat stress dan bosan pada rutinitas sehari-hari. Program yang diusung merupakan hasil dari analisis data dan lapangan, dimana merupakan kebutuhan pokok sehari-hari dari penghuninya yaitu makanan. Makanan yang dimaksud merupakan makanan yang melambangkan ciri khas dari berbagai provinsi di Indonesia, berupa kuliner nusantara, yang dimana kuliner nusantara merupakan salah satu kebanggaan terbesar bagi Indonesia, namun semakin lama semakin sedikit yang mengetahui jenis-jenisnya. Maka dari itu, 'Anjungan Kuliner Nusantara' ini digunakan sebagai suatu wadah untuk memperkenalkan kembali kuliner nusantara, dan juga dapat digunakan untuk pergelaran kuliner nusantara. Konsep anjungan kuliner nusantara ini adalah memasukkan salah satu unsur khas dalam kuliner nusantara yaitu daun pisang, yang dimana sering digunakan sebagai penambah rasa dan harum hingga sebagai wadah, yang melambangkan anjungan kuliner nusantara ini merupakan wadah dari perkulineran nusantara di Jakarta.
\end{abstract}

Kata kunci: Jakarta, Kuliner Nusantara, Metropolis, Pariwisata.

\begin{abstract}
Jakarta is one of the Metropolis Cities in Indonesia, which has a high level of stress and fatigue, that comes from various factors, including repetitive patterns of daily activities, traffic jams, pollution and so on. This is one example of the importance of recreational tourism in a metropolis to reduce stress levels and get bored in daily routines. The program that is carried out is the result of data analysis and field, which are the daily basic needs of the occupants, namely food. The intended food is a food that symbolizes the characteristics of various provinces in Indonesia, in the form of culinary archipelago, which is where culinary archipelago is one of the biggest pride for Indonesia, but increasingly fewer and less know the types. Therefore, the 'Nusantara Culinary Pavilion' is used as a place to reintroduce the culinary archipelago, and can also be used for archipelago culinary performances. The concept of the archipelago culinary platform is to include one of the distinctive elements in the culinary archipelago, namely banana leaves, which are often used as flavor enhancers and fragrant as containers, which symbolizes the archipelago culinary platform is a container of archipelago perculineration in Jakarta.
\end{abstract}

Keywords Jakarta, Metropolis, Nusantara Culinary, Tourism

\section{PENDAHULUAN}

\section{Latar Belakang}

Jakarta merupakan kota metropolis yang di dalamnya terdiri dari berbagai aktivitas perkotaan dengan pergerakan yang cepat sehingga munculnya berbagai permasalahan umum di antaranya tingkat stress yang meningkat dari masyarakatnya. Tingkat stress tersebut dapat diatasi dengan adanya suatu wisata rekreasi yang dapat memberikan efek refreshing kepada masyarakatnya. Kuliner sendiri menjadi ide dasar dari program yang akan diberikan kepada proyek bangunan ini, hal tersebut berakar dari pernyataan Menteri Pariwisata Indonesia, Arief Yahya, Badan Ekonomi Kreatif Indonesia (Bekraf), serta . Esthy Reko Astuti selaku Deputi 
Bidang Pengembangan Pemasaran Pariwisata Nusantara Kementrian Pariwisata (Deputi B3PN), yang menyatakan bahwa kuliner Indonesia memberikan kontribusi terbesar untuk sektor ekonomi kreatif di Indonesia serta memberikan potensi terbesar jika dipadukan dengan budaya (culture).

Kuliner ke depannya akan sangat digalakkan oleh pemerintah, untuk pemasaran Indonesia baik kepada wisatawan domestik maupun wisatawan mancanegara. Di Jakarta sendiri belum adanya kuliner nusantara yang bergabung dalam suatu tempat, sehingga penikmatnya kesulitan untuk merasakan berbagai masakan khas dari berbagai wilayah di Indonesia dan berkurangnya minat masyarakat terhadap kuliner nusantara itu sendiri. Oleh karena itu, diperlukannya suatu wadah untuk menampung berbagai macam kuliner khas nusantara, yang berupa 'Anjungan Kuliner Nusantara', yang dimana para pengunjungnya bukan hanya dapat terhibur namun juga mendapatkan ilmu dan pengetahuan mengenai berbagi macam kuliner nusantara yang ada, dan diharapkan dapat menjadi sebuah media promosi untuk memperkenalkan keberagaman dan keunikan kuliner nusantara dari masing-masing wilayah Indonesia.

\section{Permasalahan}

Dalam perancangan proyek anjungan kuliner nusantara ini, terdapat beberapa permasalahan yang perlu dijawab sebagai perwujudan pencapaian proyek yang tepat guna, di antaranya: kuliner yang terdapat di Jakarta sangat beraneka ragam, sehingga muncul persaingan antara kuliner lokal dan kuliner non-lokal yang memberikan pertanyaan bagaimana agar para pengunjung melakukan kunjungan berkurang meski terdapat banyak tempat wisata kuliner lainnya; pemilihan tapak dan lingkungan sangat mempengaruhi keberlangsungan suatu proyek, maka muncul pertanyaan apa sajakah faktor yang mempengaruhi agar teciptanya hubungan timbal balik positif antara program dan juga lingkungan sekitarnya; Anjungan kuliner nusantara dirancang untuk mewadahi kegiatan-kegiatan yang dapat mengenalkan dan melestarikan berbagai kuliner khas nusantara yang menimbulkan pertanyaan perlu adanyakah suatu program-program pendukung agar mendatangkan lebih banyak pengunjung lagi; dan sebagai sarana rekreatif dan edukatif, anjungan kuliner ini hendaknya dapat memberikan tampilan yang membangkitkan rasa kagum dan berkesan bagi pengunjungnya, bagaimanakah menciptakan dan menonjolkan ekspresi bangunan anjungan kuliner nusantara yang ikonik sehingga memberikan perasaan tersebut.

\section{Tujuan Proyek}

Adapun tujuan dari penulisan ini adalah agar dapat memberikan pengalaman ruang yang berbeda dalam hal kuliner dan nenambah pengetahuan mengenai kuliner yang ada, sehingga dapat menghibur dan menambah ilmu bagi para pengunjungnya; sebagai sarana untuk kegiatan di dunia kuliner; memberikan wadah untuk melestarikan masakan nusantara agar kuliner khas nusantara lebih dikenal dan dapat bersaing dengan masakan dari luar negeri.

\section{METODE}

Studi literatur yaitu dengan melakukan kajian teori serta mengumpulkan dan menganalisis beberapa buah preseden untuk menghasilkan dasar-dasar program perencanaan dan perancangan arsitektural. Studi lapangan yaitu proses kegiatan pengungkapan fakta-fakta melalui observasi/pengamatan dan wawancara dalam proses memperoleh keterangan atau data dengan cara terjun langsung ke lapangan. Melakukan wawancara serta diskusi dengan pihak pengelola Taman Mini Indonesia Indah dalam pemilihan tapaknya. Menganalisis berbagai data yang telah dikumpulkan dan menyimpulkannya berupa konsep bangunan, zoning, program ruang, sirkulasi dan lain sebagainya. 


\section{DISKUSI DAN HASIL}

Konsep anjungan kuliner nusantara yang terletak di kawasan Taman Mini Indonesia Indah (TMII) ini adalah suatu wadah untuk menampung berbagai kegiatan perkulineran nusantara di Jakarta yang dilambangkan dengan daun pisang yang merupakan salah satu ciri khas masakan kuliner nusantara. Bentuk massanya berbentuk seperti daun pisang sesuai dengan konsep bangunannya. Berada pada kawasan TMII yang merupakan kawasan pelestarian kebudayaan Indonesia di Jakarta, dimana untuk masuk ke kawasannya harus melalui akses pintu utama yang berjumlah tiga.

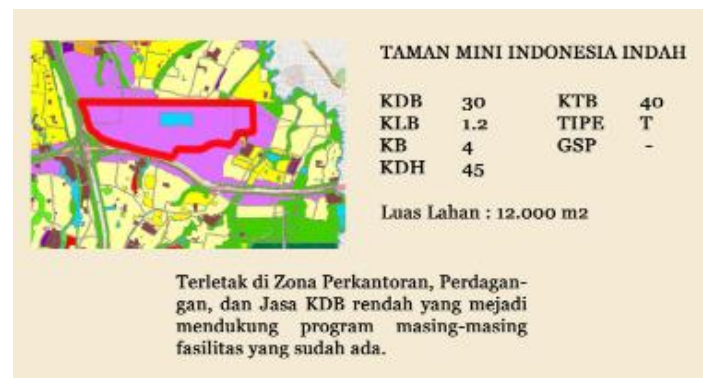

Gambar 1. Analisis Kawasan

Sumber: Data Pribadi

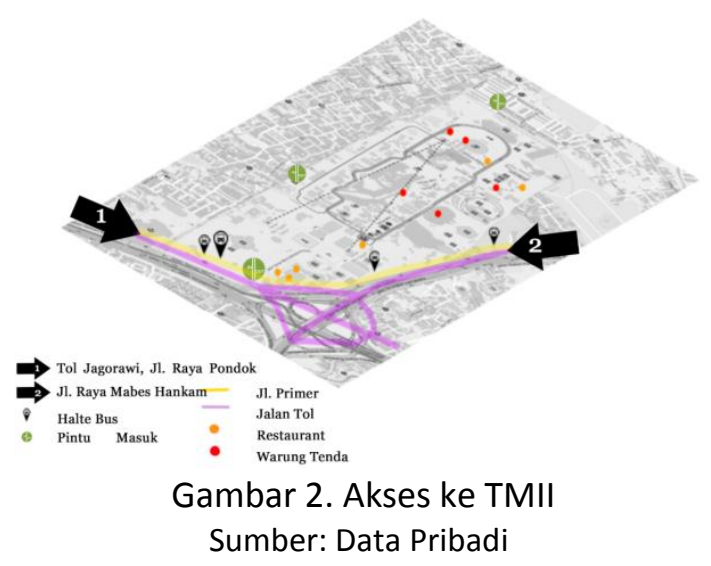

Massa diletakkan berdasarkan garis aksis yang terbentuk dari istana anak, museum IPTEK dan juga pecel madiun yang kemudian dianalisa terhadap lingkungan sekitar seperti yang terlihat pada gambar 4. Lihat Gambar 5.

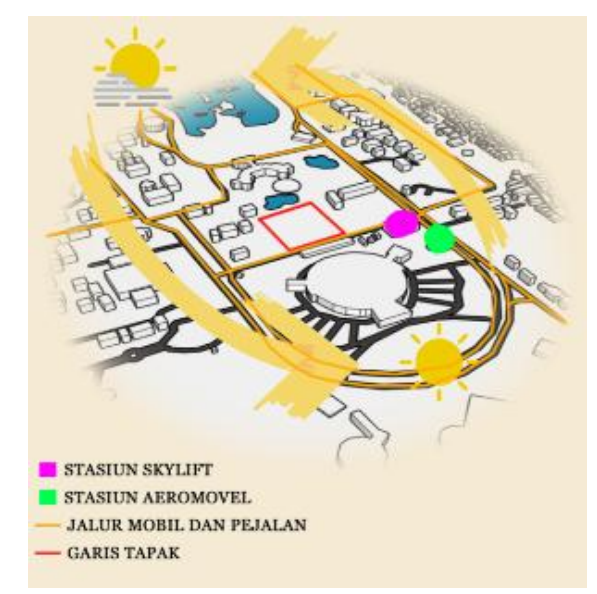

Gambar 3. Analisis Tapak Sumber: Data Pribadi 


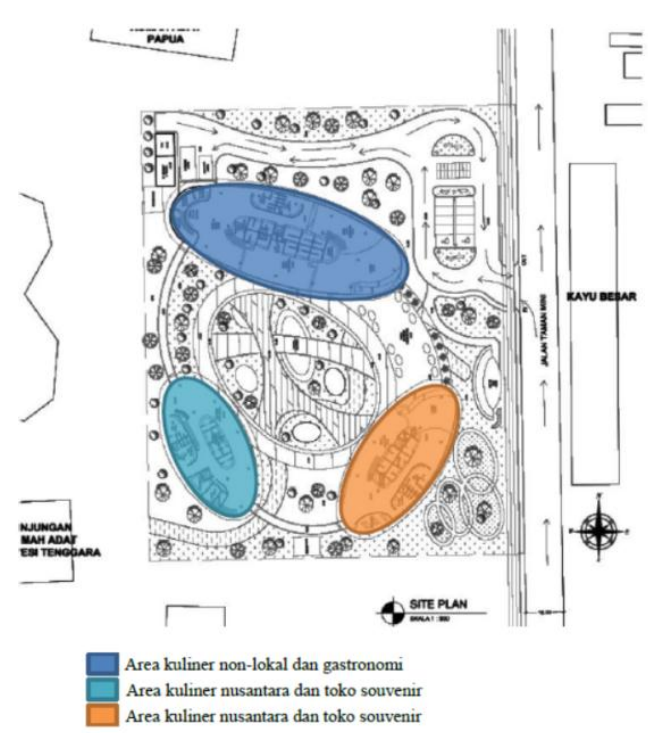

Gambar 4. Peletakan Massa Bangunan Sumber: Data Pribadi

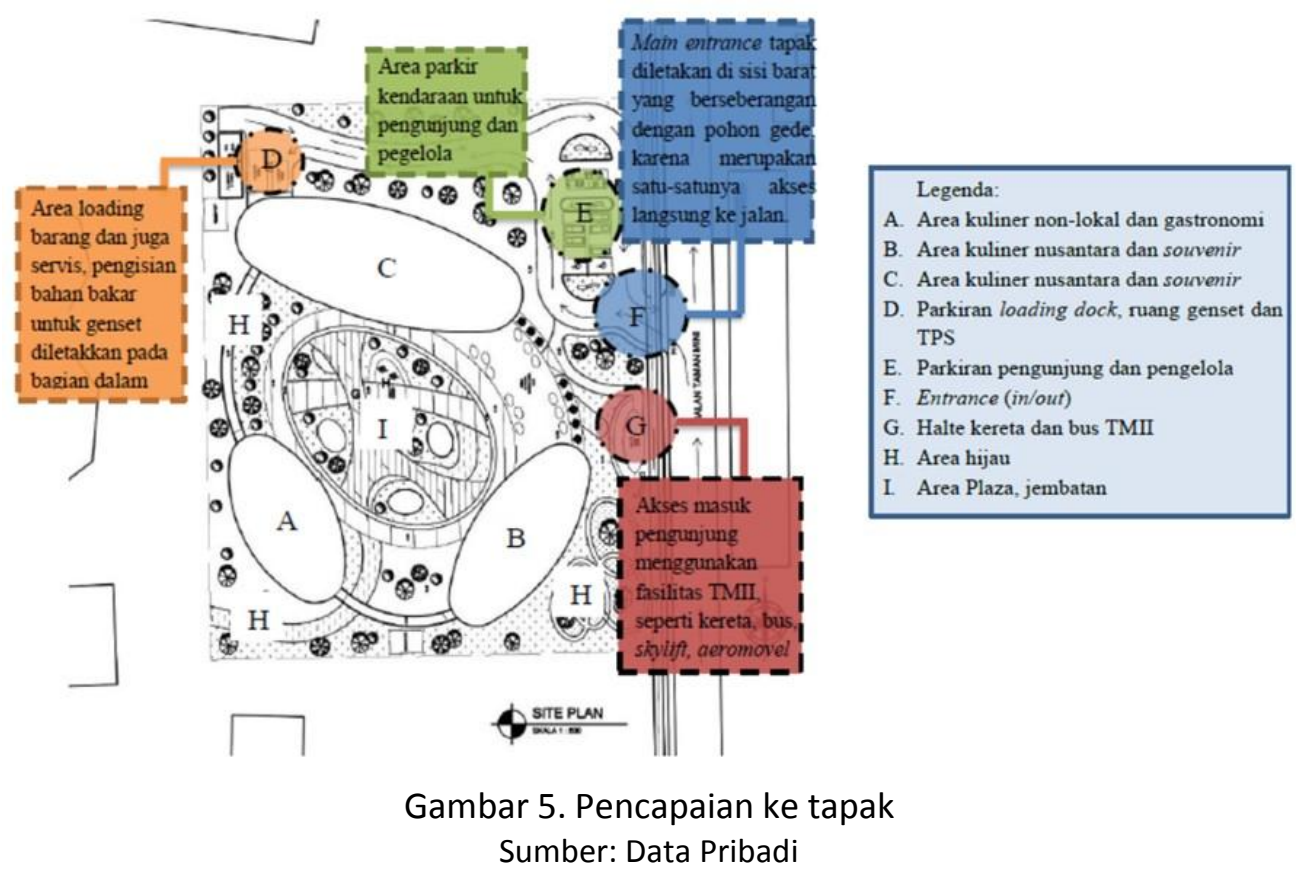

Untuk dapat menuju tapak terdapat beberapa akses yang didukung dari TMII, diantaranya menggunakan skylift, kereta aeromovel, serta halte bus dan kereta yang berada tepat di tapak. Pencapaian utama bagi pengunjung dibuka pada arah timur tepatnya berada berseberangan dengan pohon gede yang merupakan jalan akses satu-satunya. Pencapaian ini ditujukan bagi pengunjung berkendaraan pribadi maupun pejalan kaki. Pencapaian ke tapak sendiri bagi pejalan kaki dapat melalui akses kendaraan umum yang disediakan pihak Taman Mini Indonesia Indah.

\section{Sirkulasi Kendaraan}

Sirkulasi kendaraan kearah tapak berada pada sisi timur dari tapak yang berseberangan dengan pohon gede, akses kendaraan yang masuk kedalam tapak terbatas dikarenakan di kawasan TMII sendiri telah disediakan tiga buah parkiran besar untuk menampung kendaraan mobil pribadi, karena konsep dari TMII sendiri memang lebih mengarah kepada pejalan kaki 
agar ramah lingkungan. Pada tapak sendiri kurang lebih 500 meter terdapat parkiran terbesar TMII.

\section{Sirkulasi Pejalan Kaki}

Sirkulasi pejalan kaki dirancang dengan lebih banyak bentuk pelataran terbuka dengan menggunakan konblok. Jalur pedestrian dibuat mengarah ke plaza ditengah dimana menjadi titik temu dari ketiga massa bangunan yang dimana dihubungkan dengan menggunakan jembataan kayu, dan juga terdapat restoran outdoor, gazebo-gazebo, tempat duduk-duduk taman serta kolam dan pepohonan yang rindang yang terpisah dari sirkulasi kendaraan.

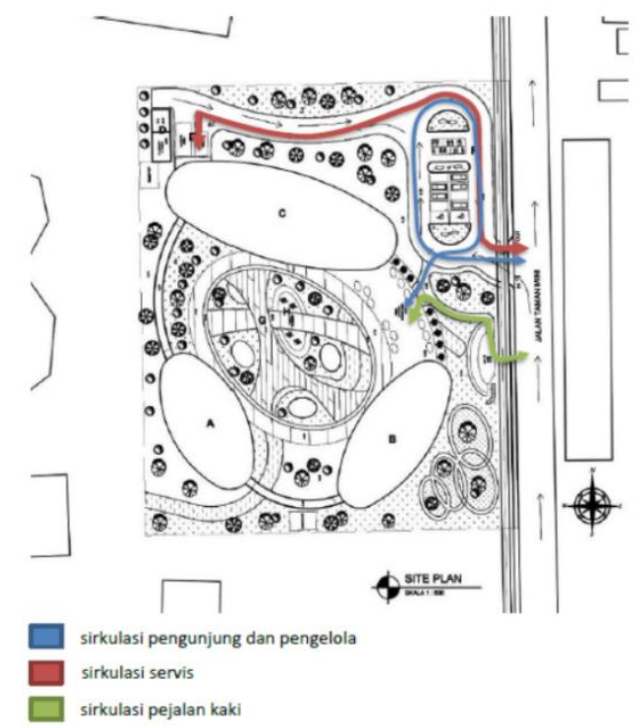

Gambar 6. Sirkulasi Tapak Sumber: Data Pribadi

Pada bagian ruang luar dipisah menjadi beberapa bagian, antara lain area penerimaan dan peralihan (yang menghubungkan massa A dan massa B yang berfungsi sebagai area jajanan kuliner khas Indonesia), area untuk berinteraksi pengunjung dengan pengunjung lainnya serta dengan lingkungan sekitar (berupa gazebo, restoran outdoor, serta jembatan dan tamantaman), dan buffer berupa taman/ ruang terbuka hijau yang tersebar di sekitar tapak.

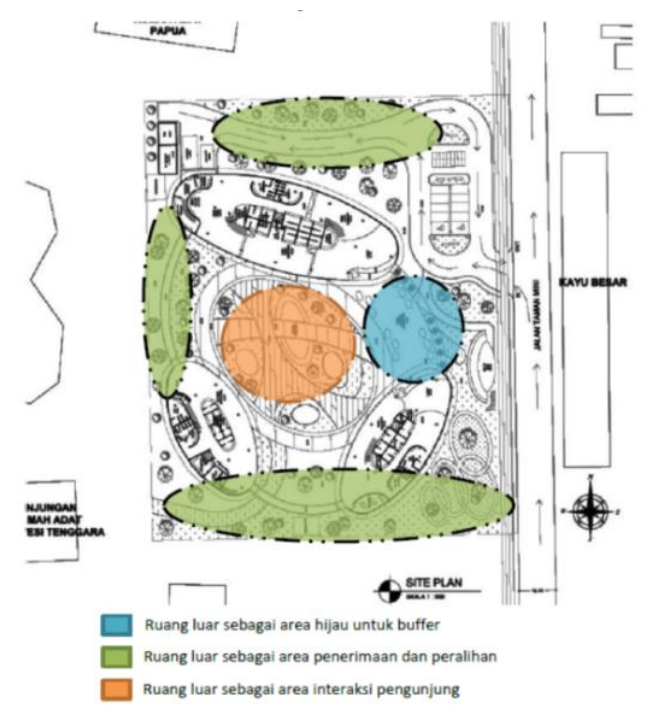

Gambar 7. Ruang Luar Bangunan

Sumber: Data Pribadi 


\section{Penampilan bangunan}

Tampilan pada bangunan merupakan kombinasi antara arsitektur tropis dan juga modern, terbentuk atas perpaduan antara bidang vertikal dan horizontal yang disertai dengan tampilan berbahan dasar kayu yang memberikan kesan tropis dan juga ringan sekaligus sebagai penambah askes estetik pada bangunan.

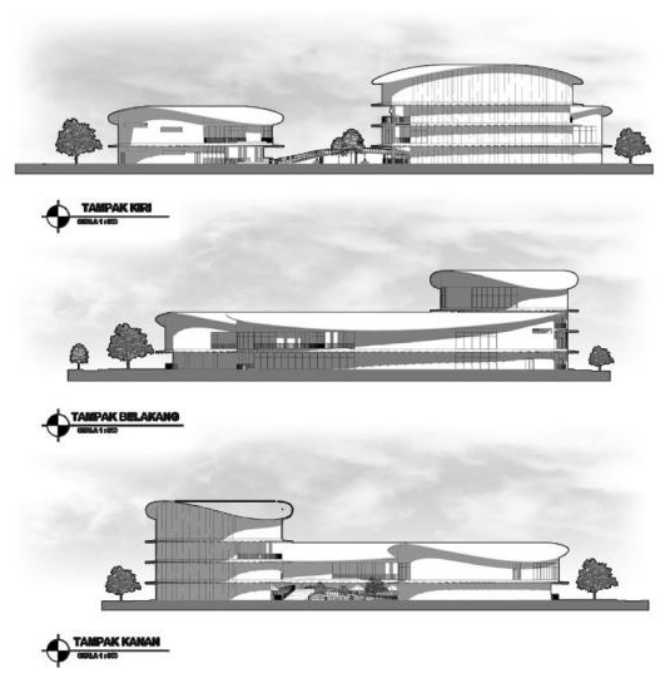

Gambar 8. Tampak Bangunan Sumber: Data Pribadi

\section{Ruang Dalam Bangunan}

Ruang kitchen lab gastronomi, berada pada lantai 3 pada massa A (lihat gambar 6), merupakan ruangan kelas yang digunakan untuk belajar mengenai kuliner nusantara dengan cara terjun langsung memasak.

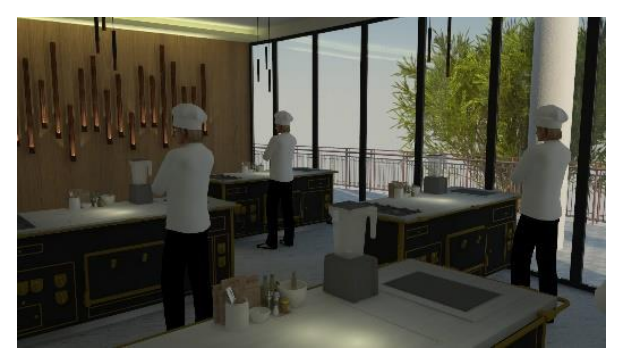

Gambar 9. Kitchen Lab Gastronomi Sumber: Data Pribadi

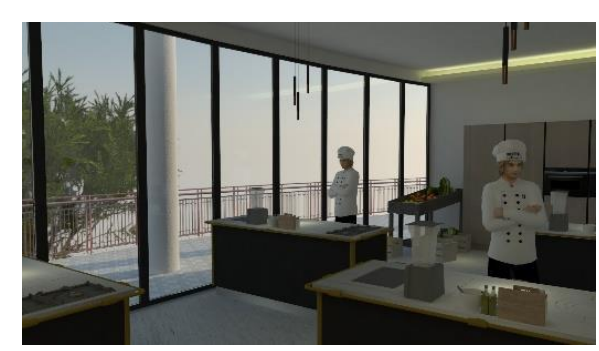

Gambar 10. Kitchen Lab Gastronomi

Sumber: Data Pribadi

Ruang restoran gastronomi, berada pada lantai 4 pada massa A (lihat gambar 6), pengunjung dapat memesan meja terlebih dahulu sebelum masuk ke restoran ini, karena terdapat jadwal kuliner yang terdiri dari berbagai makanan khas nusantara yang dibalut 
dengan gastronomi.

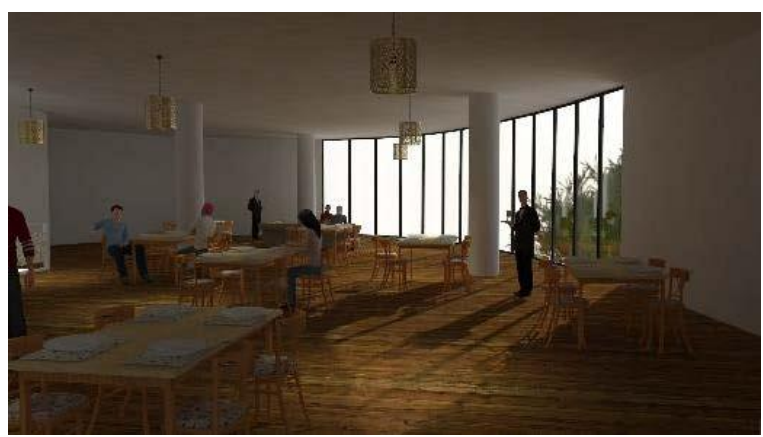

Gambar 11. Kitchen Lab Gastronomi Sumber: Data Pribadi

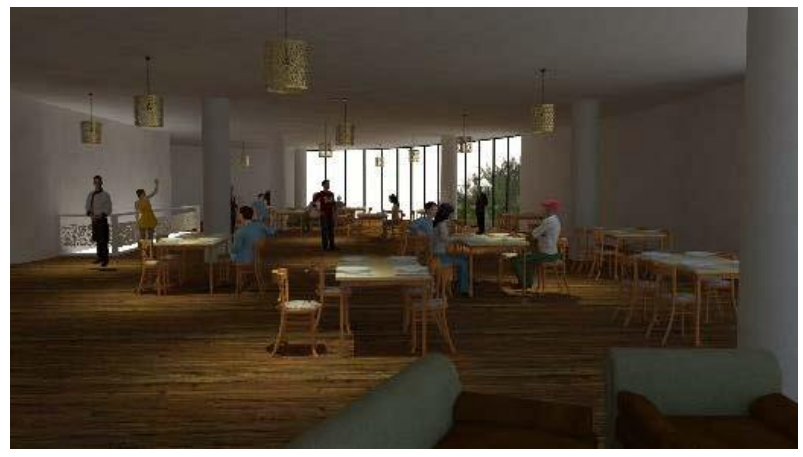

Gambar 12. Kitchen Lab Gastronomi Sumber: Data Pribadi

Struktur utama bangunan adalah struktur kolom baja yang kemudian dibungkus dengan menggunakan wood column casings agar tetap memberikan kesan ringan dan tropis, pada bagian atapnya menggunakan struktur atap rangka baja yang kemudian menggunakan penutup atap sirap.
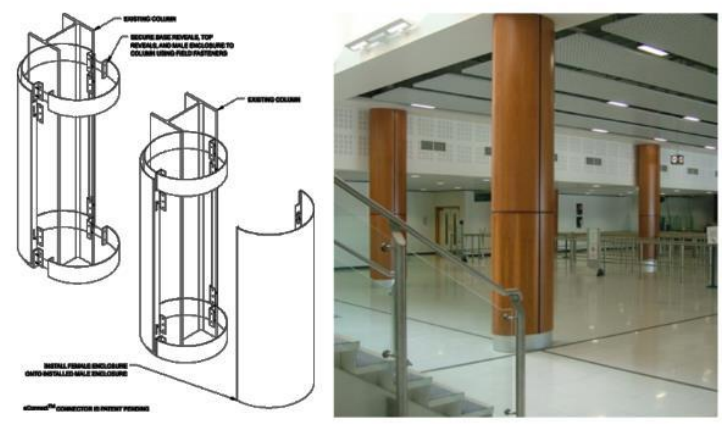

Gambar 13. Wood Column Casings

Sumber: Data Pribadi 


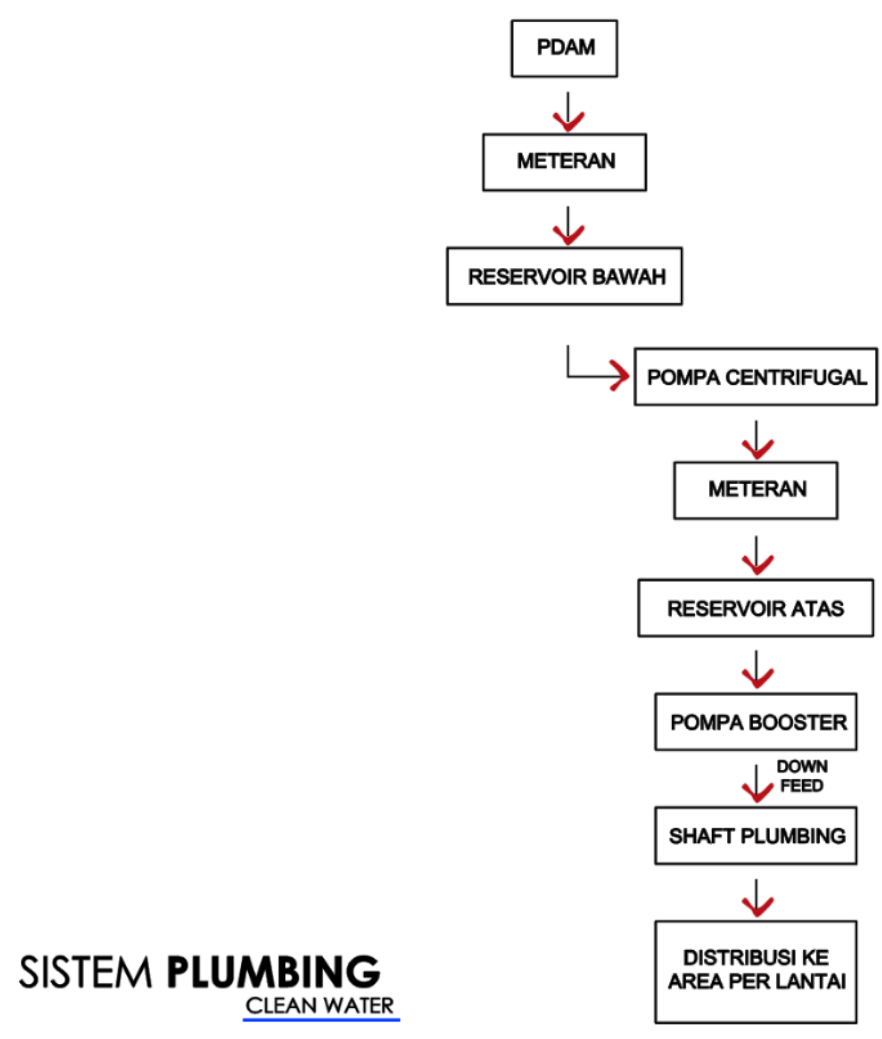

Gambar 14. Diagram Clean Water Sumber: Data Pribadi

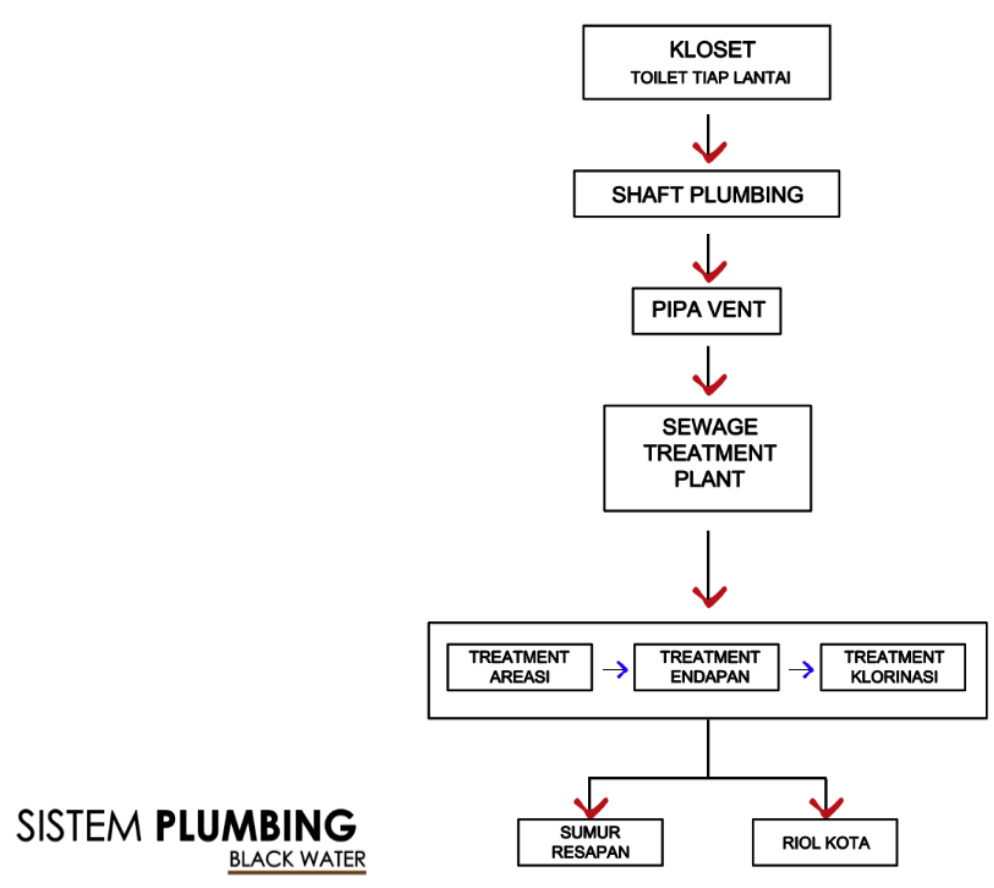

Gambar 15. Diagram Clean Water

Sumber: Data Pribadi 


\section{SISTEM PLUMBING}

GREY WATER

TOILET TIAP LANTAI

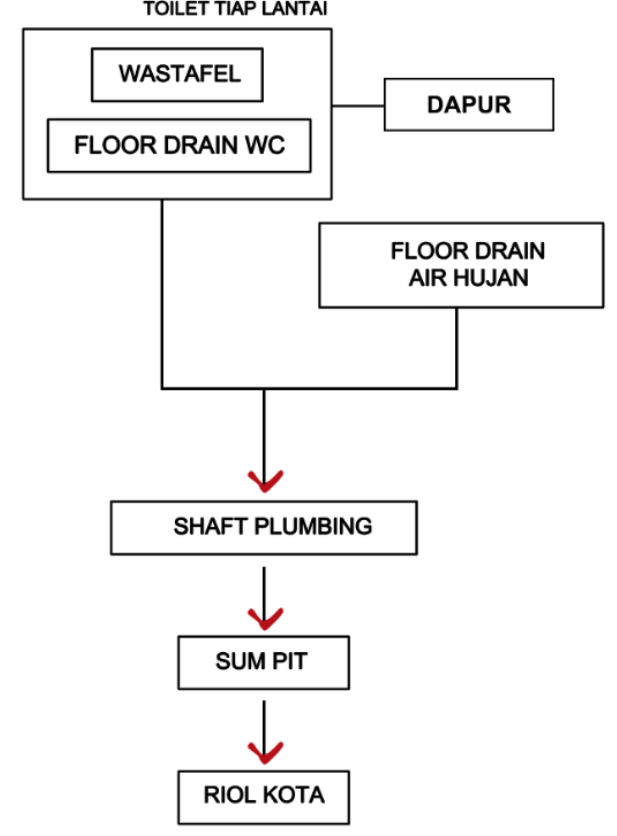

Gambar 16. Diagram Clean Water Sumber: Data Pribadi

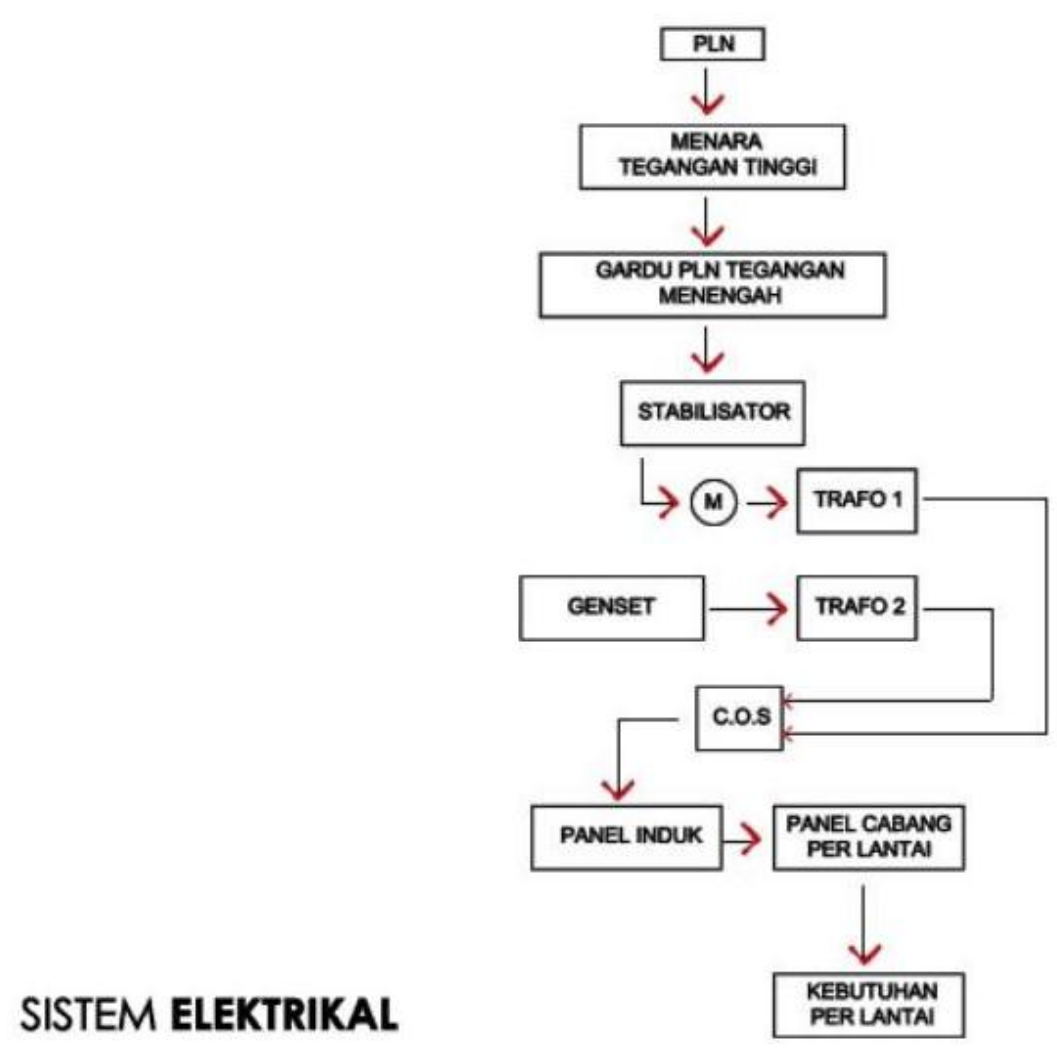

Gambar 17. Diagram Clean Water Sumber: Data Pribadi 


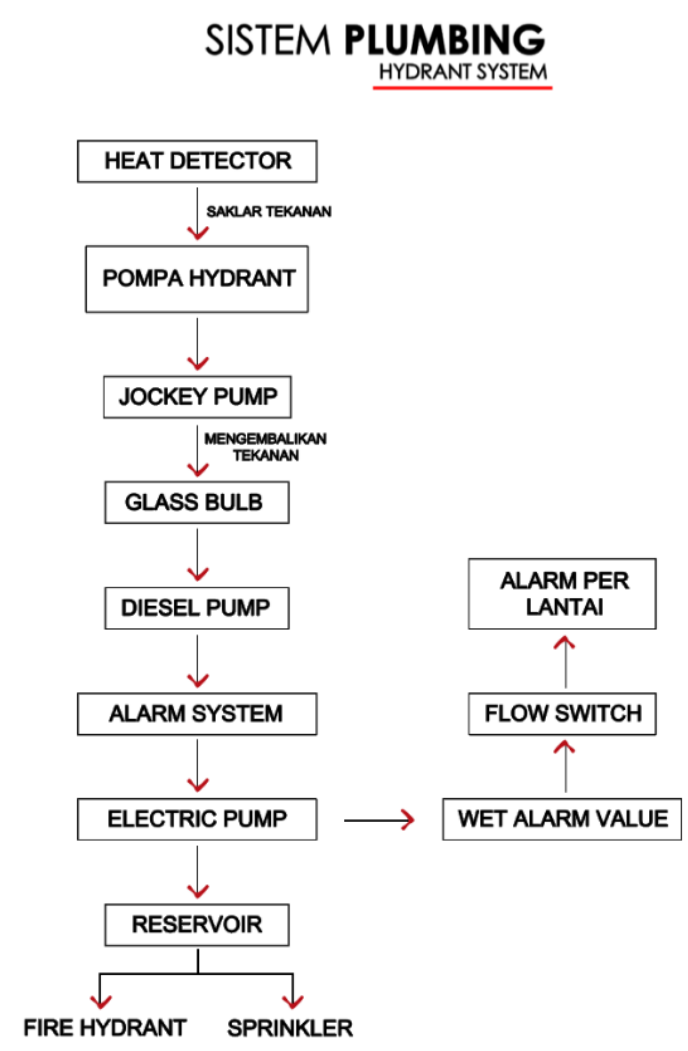

\section{Gambar 18. Diagram Clean Water}

Sumber: Data Pribadi

Ruang-ruang utilitas bangunan terletak di lantai basement yang berada pada dua massa berbeda, terkecuali reservoir atas yang diletakan di luar massa bangunan agar lebih efisien untuk digunakan pada ketiga massa bangunan.

\section{KESIMPULAN DAN SARAN}

Kuliner nusantara merupakan salah satu kekhasan Indonesia yang perlu dilestarikan keberadaan dan kerberlangsungannya. Di Jakarta sendiri yang merupakan kota metropolis yang besar, walaupun terdapat berbagai tempat wisata namun belum adanya suatu pariwisata yang mengusung kuliner khas nusantara, yang menurut data yang disebutkan oleh Menteri Pariwisata Indonesia, kuliner merupakan suatu daya tarik terkuat dalam dunia pariwisata dalam mendatangkan wisatawan pada suatu wilayah.

Kuliner sendiri merupakan suatu kebutuhan pokok manusia yang kemudian juga berkembang menjadi kebutuhan tambahan bagi penikmatnya, hal tersebut dikarenakan pengertian kuliner saat ini bukanlah hanya kegiatan mengisi perut saja, melainkan mengalami pengalaman baru dan cita rasa yang unik dari suatu hidangan.

Proyek ini mencoba menyelesaikan permasalahan wisata di wilayah perkotaan, dengan melakukan pendekatan kepada kebutuhan utama bagi penghuninya, yang kemudian dikembangkan melalui proses analisis data, hingga mencapai program yang dapat dikatakan tepat dan dibutuhkan dalam pariwisata perkotaan. Proyek ini sendiri berdiri di kawasan Taman Mini Indonesia Indah yang merupakan kawasan kebudaayan Indonesia terbesar yang berada di Jakarta, sehingga antara lingkungan sekitar dengan proyek terdapat timbal balik yang menguntungkan kedua belah pihak. Dalam perancangan bangunan ini, dilakukan berbagai analisis dengan lingkungan sekitar dan juga mengusung konsep analogi dalam pembentukan massanya. Beberapa hal yang perlu diperhatikan diantaranya, perancangan bangunan harus memberikan kesan ramah lingkungan dan tropis baik dari tampilan fasad bangunan, penggunaan material, hingga atribut-atribut lainnya, yang berfungsi untuk 
meningkatkan kualitas bangunan tanpa menghilangkan hubungan timbal baliknya dengan lingkungan sekitar.

\section{REFERENSI}

Afif, Irfan. (2015). 24 November, Pentingnya Sektor Kuliner untuk Kemajuan Pariwisata Indonesia, diunduh 29 Agustus 2018, <http://www.halhalal.com/pentingnya-sektorkuliner-untuk-kemajuan-pariwisata-indonesia/>

Agmasari, Silvita. (2016). 23 September, Apa Bedanya Wisata Kuliner dan Wisata Gastronomi?, diunduh 5 Agustus 2018, <https://travel.kompas.com/

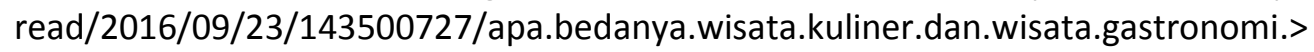

Akademi Gastronomi Indonesia. 2016, Akademi Gastronomi Indonesia, diunduh 9 September 2018, <http://akademigastronomi.or.id/tentang-kami/>

Archdaily. (2011). 30 Desember, Basque Culinary Center / VAUMM, diunduh 11 Agustus 2018, <https://www.archdaily.com/196035/basque-culinary-center-vaumm>

Archdaily. (2015). 13 Agustus. Food Villa Market / I Like Design Studio, diunduh 11 Agustus 2018, <https://www.archdaily.com/771779/food-villa-market-i-like-design-studio>

Archdaily. (2011). 23 Maret. Institute for the Culinary Arts / HDR Architecture, diunduh 12 Agustus 2018,<https://www.archdaily.com/121226/institute-for-the-culinary-arts-hdrarchitecture>

Architizer. (2010). Institute for the Culinary Arts, diunduh 14 Agustus 2018, <https://architizer.com/projects/institute-for-the-culinary-arts/>

Bisnis. (2014). 12 Desember. Indonesia Menuju Destinasi Wisata Kuliner Terfavorit Dunia. Diperoleh 21 Agustus 2018, <http://m.bisnis.com/amp/read/20141212/12/382066/indonesia-menuju-destinasiwisata-kuliner-terfavorit-dunia>

Diela, Tabita. (2014). 29 September. Posisi Industri Kuliner Cukup Strategis bagi Perekonomian RI. Diperoleh 12 Agustus 2018, <https://ekonomi.kompas.com/read/2014/09/29/211600926/Posisi.Industri.Kuliner.Cuku p.Strategis.bagi.Perekonomian.RI>

Gillesoie C, Cousins JA. (2001). European Gastronomy into the 21st century. Oxford:Butterworth-Heinenmann.

Juniman, Puput Tripeni. (2018). 5 Maret. Gastronomi, Pengalaman Berbeda Menyantap Kuliner. Diperoleh 23 Agustus 2018, <https://www.cnnindonesia.com/gayahidup/20180305180404-262-280650/gastronomi-pengalaman-berbeda-menyantapkuliner>

Kementerian Pariwisata. (2017). 29 Maret. Dialog Gastronomi Nasional ke-2 dan Promosi Kuliner Wakatobi. Diperoleh 7 Agustus 2018, $<$ http://kemenpar.go.id/asp/detil.asp?c=16\&id=3528>

Kumparan. (2018). 4 Juni. Gastronomy: History, Culture and Pleasure, diunduh 8 September 2018, <https://kumparan.com/keuken-bandung/gastronomy-history-culture-andpleasure>

Maengkom, Daniel. (2015). 7 November, Antara Gastronomi dan Kuliner, diunduh 3 September 2018, <https://indogastronomi.wordpress.com/2015/11/07/antara -gastronomi-dan-kuliner/>

Markhamah, Sulis Setia. (2014). 15 April, Durian Kopi Luwak Khas Lampung, diunduh 7 September 2018, <http://www.saibumi.com/artikel-2476-durian-kopi-luwak-khaslampung.html>

Natahsa, Devona. (2014). Perancangan Interior One-Stop Wisata Kuliner Khas Indonesia [skripsi]. Jakarta (ID): Bina Nusantara

Novianti, Yessica. (2015). Perancangan Interior pada Pusat Kuliner Nusantara di Jakarta [skripsi]. Jakarta (ID): Bina Nusantara 
Nugraha, Teguh. (2015). 4 Februari, Definisi Wisata Kuliner, diunduh 6 September 2018, <https://omguguh.wordpress.com/2015/02/04/definisi-wisata-kuliner/>

Rahman, Fadly. (2016). Jejak Rasa Nusantara: Sejarah Makanan Indonesia, Jakarta: Gramedia.

Refdino, Asshar. (2013). Pengertian Pariwisata, diunduh 28 Agustus 2018, <http://assharrefdino.blogspot.com/2013/11/pengertian-pariwisata.html>

Republika. (2018). 26 Agustus, Dibanding Kuliner, Gastronomi Indonesia Masih Belum Populer, diunduh 5 September 2018,<https://www.republika.co.id/ amp_version/n47qkm>

Savarin, Brillat. (1854). Physiology of Taste: Or, Meditations on Trancendental Gastronomy. Philadelphia: Lindsay \& Blakiston.

Specht, Jan. (2014). Architectural Tourism: Building for Urban Travel Destinations. Germany: Springer Gabler.

Tim Dapur Demedia. (2010). Kitab Masakan Nusantara: Kumpulan Resep Pilihan dari Aceh sampai Papua. Semarang: Demedia

World Tourism Organization. (2012). Global Report on Food Tourism. Spain: Centro Espanol de Derechos Reprograficos

Yusufadisyukur, Elifas Omega. (2017). 13 Juli.Pariwisata: Sinergi Pengembangan Wisata Kuliner dan Agrowisata, diunduh 2 Spetember 2018, dari <http://iaas.or.id/pariwisata-sinergipengembangan-wisata-kuliner-dan-agrowisata/>

Vaneer, Sue. (2016). 17 Desember, Arti Kata "metropolis" Makna Pengertian dan Definisi, diunduh 21 Agustus 2018, <https://artikbbi.com/metropolis/> 